\title{
UPACARA MACARU SANAK MAGODEL DI SASIH KESANGA DESA ADAT ABIANTUWUNG TABANAN
}

\author{
I Wayan Martha \\ Ida Bagus Gede Wijaya \\ Fakultas Ilmu Agama dan Kebudayaan \\ Universitas Hindu Indonesia \\ Denpasar
}

\begin{abstract}
ABSTRAK
Agama Hindu di Bali sangat terkenal dalam hal upacara. Upacara Agama Hindu di Bali dibagi menjadi lima bagian yang disebut upacara Panca Yadnya, yaitu lima korban suci yang tulus iklas. Upacara Macaru Sanak Magodel di Sasih Kesanga Desa Adat Abiantuwung merupakan ritual yang tergolong ke dalam upacara Bhuta Yadnya. Upacara Macaru Sanak Magodel di Sasih Kesanga Desa Adat Abiantuwung, Kabupaten Tabanan, karena dalam upacara macaru sasih kesanga di wilayah desa Adat lain, hanya menggunakan caru panca sata tanpa tambahan "suku pat" atau hewan berkaki empat apapun, tetapi desa adat Abiantuwung menggunakan hewan anak sapi untuk tambahannya serta dilaksanakan setiap tahun. Keunikan inilah yang sangat menarik diteliti dan dibuat suatu karya ilmiah.
\end{abstract}

Kata kunci: Mecaru Sanak Magodel, Upacara

\section{ABSTRACT}

Hinduism in Bali is very famous in terms of ceremonies. Hindu rituals in Bali are divided into five parts called the Panca Yadnya ceremony, namely five sincere victims. The Macaru Sanak Magodel ceremony in Sasih Kesanga Abiantuwung Traditional Village is a ritual that belongs to the Bhuta Yadnya ceremony. Macaru Ceremony of Sanak Magodel in Sasih Kesanga Abiantuwung Customary Village, Tabanan Regency, because in the ceremony the sasih kesanga macaru in the other Adat village area, only uses the caru panca sata without any additional "pat tribes" or four-legged animals, but the traditional Abiantuwung village uses child animals cows for addition and carried out every year. This uniqueness is very interesting to be researched and made a scientific work.

Keywords: Mecaru Sanak Magodel, Ceremony 


\section{PENDAHULUAN}

Dalam kehidupan sehari-hari, manusia selalu berusaha dengan kekuatan dirinya sendiri. Namun pada saat menyadari kebatasannya sebagai manusia, di sini manusia meyakini untuk menjalankan usaha religius. Selanjutnya diperlukan kekuatan lain, yaitu Tuhan sebagai sang pencipta dan ajaran agama sebagai tumpuan hidup. Agama dijadikan landasan berprilaku dalam hubungan lingkungan, sesama serta Tuhan. Bagi umat Hindu, usaha yang lazim digunakan sebagai usaha menjembatani sekaligus mereflesikan hubungan diri dengan Tuhan adalah melalui rangkaian upacara Yadnya. Yadnya dipakai sarana untuk mengekspresikan hubungan manusia dengan Sang Pencipta. Hal ini dilakukan mengingat kwalitas dari masing-masing individu tidak sama dan disebabkan pula oleh kelahiran manusia itu sendiri yang penuh dengan kegelapan (Tim Penulis, 2000:8).

Agama Hindu memeiliki tiga kerangka dasar yaitu tattwa (filsafat), Upacara (ritual), Susila (etika). Agama Hindu di Bali sangat terkenal dalam hal upacara. Di Bali banyak kita lihat masyarakat mengadakan suatu upacara yadnya. Walaupun suatu desa melakukan upacara yadnya yang sama akan tetapi kemungkinan ada sedikit perbedaan karena itu di sesuaikan dengan desa, kala, dan patra masingmasing. Upacara Agama Hindu di Bali dibagi menjadi lima bagian yang disebut upacara Panca Yadnya, yaitu lima korban suci yang tulus iklas. Adapun bagian dari Upacara Panca Yadnya itu adalah : Dewa Yadnya adalah korban suci yang tulus iklas kepada Ida Sang Hyang Widhi Wasa dan seluruh manifestasi-Nya, Rsi Yadnya adalah persembahan kepada para Rsi, Pitra Yadnya adalah persembahan suci yang ditujukan kepada para roh-roh suci dan leluhur, Manusa Yadnya adalah penyucian secara spiritual terhadap seseorang dari dalam kandungan sampai akhir hidupnya, Bhuta Yadnya adalah korban suci atau persembahan kepada para Bhuta Kala dan kekuatan alam. Menurut Nada Atmaja I Made, dkk (2011: 35) dalam bukunya yang berjudul "Etika Hindu" mengatakan bahwa Tanpa yadnya Tuhan, alam semesta beserta isinya tidak akan ada oleh karena itu betapa pentingnya yadnya itu bagi umat Hindu.

Melaksanakan Upacara Yadnya adalah merupakan langkah yang diyakini sebagai kegiatan beragama Hindu yang amat penting. Dimana Yadnya merupakan persembahan tulus ikhlas atau rasa bhakti yang bertujuan untuk mencari kebahagiaan yang kekal dan abadi (Moksa). Yadnya juga disebut sebagai salah satu penyangga bumi. Demikian disebutkan dalam kitab Atharwa Weda. Pemeliharaan kehidupan di dunia ini dapat berlangsung terus sepanjang Yadnya adalah pusat terciptanya alam semesta atau Bhuwana Agung sebagai diuraikan dalam Yajur Weda. Disamping sebagai pusat terciptanya alam semesta yadnya juga merupakan sumber berlangsungnya perputaran kehidupan yang dalam Kitab Bhagawadgita disebut Cakra Yadnya. Kalau Cakra Yadnya ini tidak berputar maka kehidupan ini akan mengalami kehancuran.

Pelaksanaan Upacara atau Yadnya yang dimuat dalam kerangka dasar Agama Hindu, di dalam pelaksanaannya pada masing-masing desa adat di Bali sangat berbeda-beda, lazimnya disebut Desa Mawa Cara atau Desa Kala Patra yaitu : pelaksanaan upacara atau yadnya disesuaikan dengan daerah-daerah setempat. Hal 
ini khususnya di Bali disebut dengan Desa, Kala dan Patra dapat diuraikan yaitu : Desa adalah tempat dari pelaksanaannya upacara yadnya, Kala adalah Dauh atau waktu kapan pelaksanaannya upacara tersebut, Patra adalah bagaimana keadaan dan bentuk pelaksanaannya upacara atau yadnya itu. (Mantra, 1997-1998:153).

Bhuta Yadnya terdiri dari dua kata, yaitu Bhuta dan Yajna. Bhuta akar kata "Bhu" berarti ada, jadi Bhuta artinya yang diadakan atau diciptakan, sedangkan Yajna akar kata "Yaj" artinya korban suci, Yajna adalah korban suci. Dengan demikian Bhuta Yadnya adalah persembahan atau korban suci yang ditujukan kepada para Bhutakala dengan harapan beliau tidak menganggu sehingga alam ini menjadi harmonis (Swastika, 2013:14).

Dengan melakukan upacara Bhuta Yadnya maka sifat-sifat kebaikan dan kekuatan dari makhluk itu dapat berguna bagi kesejahteraan manusia. Dalam Bhuta Yadnya, juga terkandung pengertian usaha penyupatan terhadap makhlukmakhluk rendah, sehingga mereka menjadi makhluk yang dinaikan derajatnya untuk menjalani karmanya.

Dalam Manawa Dharmasastra dijelaskan yeng termasuk Bhuta adalah unsurunsur alam serta makhluk hidup ciptaan Tuhan, seperti tanah, air, api, tumbuhtumbuhan, binatang, dan sebagaiannya. Secara kenyataan unsur-unsur serta ciptaan itulah yang membantu kehidupan didunia ini, dan sebagai tanda terimakasih, diselenggarakan pula yadnya kepada-Nya. (Midastra, 2007:48).

Pelaksanaan Bhuta Yadnya ini sering disebut dengan istilah Macaru. Kata Caru berasal dari dua suku kata yaitu suku kata "Car" yang artinya raup, campur, cantik dan suku kata "Ru" berasal dari suku kata "Roh" kemudian menjadi Rahu, dan akhirnya menjadi "Ruu" yang artinya kala, musuh, kala rau, kekotoran bersifat spiritual (kekuatan asuri sampad yang bersifat negatif) untuk dijadikan supaya suci (bhuta hita) agar terpeliharanya keseimbangan, keselarasan dan keserasian Bhuwana Agung dengan Bhuwana Alit. (Sudarsana, 2001:26)

Upacara Mecaru dilakukan oleh umat pada setiap Pelemahan Rumah, Banjar, Desa, Pura dan bahkan suatu Wilayah. Caru Palemahan, dilaksanakan untuk keharmonisan dari suatu wilayah. Caru Sasih, jelas ditujukan untuk keharmonisan waktu atau musim demikian juga halnya Caru Dewasa, untuk baiknya suatu upacara yang akan diselenggarakan mengingat waktu pelaksanaan yadnya tersebut ada baik dan buruknya. (Swastika, 2013:14).

Dalam tingkatan ada aneka jenis Caru mulai Panca Eka Sata dengan jenisnya, yaitu Caru Ayam Brumbun, Ayam Wiring, Ayam Putih dan sebagainya menurut keperluannya. Caru Manca Warna dengan menggunakan ayam 5 ekor dengan masing-masing warnanya. Caru Panca Sata, yaitu caru Manca Warna ditambah dengan "meri blang kalung" yang juga dibuat sama seperti ayam lainnya. Caru Panca Sanak, caru seperti diatas ditambah dengan Anjing Bang Bungkem yang dibuat sama seperti ayam mancawarna diatas. Caru Panca Sanak Madurga. Caru yang sama dengan diatas, dan tambahan suku empat adalah berupa Kucit Selem butuhan (babi plon). Tawur adalah caru yang tergolong besar. Yang tergolong tawur adalah : Mencaklud, yakni Caru yang dasarnya adalah Panca Sanak, di tambah dengan Angsa dan Kambing serta membuat nasi tawur sebagai simbol untuk membersihkan bhumi kita ini. Malik Sumpah yakni jenis Caru yang dasarnya juga Panca Sanak, dengan tambahan di samping Angsa, 
Kambing juga seekor “Godel Merah”. Bila jenis Caru di atas mempergunakan seekor Kerbau, maka tawur itu disebut Labuh Gentuh atau Tawur Agung. Lebih besar dari tingkat ini terdapat Tawur Panca Walikrama, Tawur Tribhuvana, Eka Bhuvana dan Eka Dasa Ludra.

Dalam Lontar Cundarigama menyebutkan

Tilem Kesanga

Atta ring cetra masa, Tilem Kunang, sasucening watek Dewata Kabeh, hana ring telenging samudra, met sarinning amrta kamandalu, yoga mwang kabeh ngaturaken puja krti, ring sarwa Dewata, keyeki kramania. Catur daci ikang krsna paksa, agawyakna Bhuta Yadnya, rikang catus pataning desa, nistania pancasata, madyana pancasanak, utamania Tawur Agung Yamaraja, pinuja dening Sang Maha Pandita, siwa budha sakawu-kawu kunang sega mancawarna, 9 tanding, iwak sakta brumbun rinancana, saha tabuh tok, arak, genahing acaru ring dengen, sambut Sang Bhutaraja mwang Sang Kalaraja.

Artinya:

Tersebutlah menjelang sasih kesanga, yang disebut Cetramasa, terutma pada bulan mati / tilem adalah hari untuk bersucian para Dewa semua, di laut, guna menikmati inti hakikat air suci kehidupan abadi. Karena itu seyogyanyalah orang-orang menghaturkan puja bakti kehadapan para Dewata, dengan tata cara sebagai berikut: Pada panglong ping 14 sasih kesanga, hendaknya melakukan upacara mecaru/ bhuta yadnya diperempatan desa pekraman. Adapun tingkatannya adalah sekecil-kecilnya dengan caru panca sata ( ayam 5 ekor ), tingkatan menengah dengan panca sanak ( dasar caru ayam 5 ekor, ditambah itik bulu sikep sebagai ulu ), sedangkan dalam tingkatan utama ialah tawur agung ( Panca walikrama ), yang memakai Yamaraja. Bhuta yadnya tersebut dipuja oleh Sang Maha Pandita ( Pedanda, Rsi, Empu ).

Dalam upacara Macaru Sanak Magodel di Sasih Kesanga Desa Adat Abiantuwung, Kabupaten Tabanan belum ada yang melakukan penelitian , akan tetapi ada beberapa penelitian yang terkait. (Ewik Umayanti. 2017) melakukan penelitian dengan judul "Upacara Macaru Godel Bang di Pura Prajapati Desa Bunutin Kabupaten Bangli”. Upacara ini dilaksanakan pada sasih kapitu Kajeng Kliwon Uwudan. Upacara diawali dengan melaksanakan pecaruan panca sata yang selanjutnya pecaruan Godel Bang setelah prosesi ini selesai warga desa Bunutin melaksanakan persembahyangan bersama di Pura Prajapati. Dan setiap warga Desa Adat Bunutin dirumah masing-masing melaksanakan matur piuning di Bhatara Hyang Guru. Setelah matur piuning semua keluarga melaksanakan pecaruan dengan ulam olahan Godel Bang. Upacara Macaru Sanak Magodel di Sasih Kesanga Desa Adat Abiantuwung, Kabupaten Tabanan sangatlah berbeda karena hanya menggunakan caru Panca Sata serta ditambah dengan olahan 
bayang-bayang (belulang) Godel dan ditempatkan di Barat Daya serta di Barat Laut menggunakan Bebek Bulu Sikep. Upacara ini dijalankan oleh pemangku Kahyangan Tiga di desa Adat Abiantuwung.

Hal ini menarik minat penulis untuk meneliti tentang Caru yang digunakan dalam upacara Macaru Sanak Magodel di Sasih Kesanga Desa Adat Abiantuwung, Kabupaten Tabanan, karena dalam upacara macaru sasih kesanga di wilayah desa Adat lain, hanya menggunakan caru panca sata tanpa tambahan "suku pat" atau hewan berkaki empat apapun, tetapi desa adat Abiantuwung menggunakan hewan anak sapi untuk tambahannya serta dilaksanakan setiap tahun. Selain makna yang terdapat dalam upacara Macaru Sanak Magodel di Sasih Kesanga cukup tinggi disamping itu penulis juga ingin mengetahui bagaimana bentuk pelaksanaan dalam upacara Macaru Sanak Magodel di Sasih Kesanga Desa Adat Abiantuwung, Kabupaten Tabanan.

\section{PEMBAHASAN}

\subsection{Bentuk Pelaksanaan Upacara Mecaru Sanak Magodel di Sasih Kesanga}

Pelaksanaan Upacara Mecaru Sanak Magodel di Sasih Kesanga Desa Adat Abiantuwung merupakan suatu tradisi yang harus dilaksanakan setiap tahun, biasanya jatuh pada bulan Maret, nemonin Tilem Kesanga tepatnya Sasih Kesanga. Selain itu upacara Macaru Sanak Magodel diyakini masyarakat dan Pemangku merupakan tradisi turun-temurun yang telah dilakukan dari leluhur sampai sekarang tanpa merubah bentuk upacara tersebut, sehingga bagi masyarakat Desa Adat Abiantuwung meyakini upacara ini dapat menyeimbangkan Bhuana Agung dan Bhuana Alit, menghilangkan leteh pada Desa dari hal-hal negatif serta baik dalam kehidupan keagamaan maupun kehidupan sosial masyarakat. Dalam bentuk pelaksanaan Upacara Mecaru Sanak Magodel di Sasih Kesanga, digunakan Teori Religi seperti yang dikemukakan oleh Koentjaraningrat Religi adalah suatu sistem kepercayaan yang dianut oleh masyarakat tradisional. Religi adalah segala sistem tingkah laku manusia untuk mencapai suatu maksud dengan cara menyadarkan diri pada kemauan dan kekuasaan mahluk-mahluk halus seperti roh-roh, dewa-dewa dan sebagainya yang menempati alam.

"Dalam upacara Mecaru Sanak Magodel, Desa Adat Abiantuwung dibagi menjadi tiga pahpahan (bagian) diantaranya Banjar Adat Abiantuwung, Banjar Adat Pasekan, Banjar Adat Koripan. Ketiga Banjar Adat tersebut mempunyai tugas berbeda dalam proses upacara ini, dari tugas tersebut yang pertama pembuatan banten upakara Caru, nunas Tirta di Pura Khayangan Tiga dan pembuatan olahan Ulam Godel. Proses ini biasanya dilaksanakan searah dengan jarum jam, sehingga ketiga Banjar Adat mempunyai tugas masing-masing" (Wawancara bersama Gusti Made Darma, tanggal 29 Maret 2019) 
Dibawah ini secara lebih rinci akan dapat diuraikan lebih jelas bentuk pelaksanaan upacara Macaru Sanak Magodel di Sasih Kesanga sebagai berikut :

1. Tahap Awal

Upacara Mecaru Sanak Magodel dimulai dari melakukan ngayah (pembuatan banten) satu minggu sebelum upacara mecaru yang dilaksanakan Serati Banten Adat Abiantuwung mempersiapkan berbagai sarana upakara yang akan digunakan dalam upacara mecaru tersebut, dengan bentuk kerja sebagai berikut :

1) Caru Panca Sata

2) Caru Bebek Bulu Sikep

3) Caru Godel

4) Ayaban Tumpeng 7 a soroh

5) Pemepekan, Pengaturan a soroh

6) Banten Pemali

7) Penebusan

8) Daksina Gede Galah

9) Banten Kalemijian

10) Tebasan Durmengala

11) Tebasan Pegoyan

12) Pengambian

13) Suci

14) Penyemek

15) Pengulapan

16) Prayascita

17) Byakaonan

18) Tegen-tegenan Lebeng Matah

19) Sanggah Caru

20) Sanggah Durga

Selanjutnya pada saat Tilem Kesanga upacara Mecaru Sanak Magodel dimulai dari Mepada di Pura Desa, sebelum Godel memasuki Pura dihaturkan Segehan Gede, kemudian setelah memasuki Pura, kaki Godel ditebas agar mengeluarkan darah di areal pura serta mengelilingi Bale Agung sebanyak tiga kali, barulah pemotongan Godel dilaksanakan di 
Banjar Adat yang telah mendapatkan tugas untuk mengolah ulam caru ini. Pemotongan dan pengolahan dilakukan oleh warga laki-laki mulai dari subuh dengan menguliti kulitnya karena yang dipakai bayangbayangnya. Daging Godel diolah menjadi tetandingan berupa : Bayuhan 99, karangan 1, lawar putih, lawar barak, don blimbing, calon 9, sate lemat 9, dan sate asem 9 dari daging Godel dipakai untuk upacara Macaru Godel Bang, serta membuat olahan daging Bebek Bulu Sikep 33 tanding. Serta membuat isi Jeron, Bayuhan Godel sebanyak jumlah pemesuan (pintu keluar) warga Desa Adat Abiantuwung.

2. Tahap Kedua

Aktivitas yang dilakukan pada tahap kedua ini mulai menginjak proses upacara Pecaruan. Masing-masing Banjar Adat mempersiapkan sarana yang digunakan di Catus Pata Desa Adat Abiantuwung, upacara ini disaksikan oleh Pemangku Khayangan Tiga, Bendesa Adat Abiantuwung, Penglingsi Puri Abiantuwung, Pemangku Prajapati, Penyarikan, Dasaran dan Tokoh Bhujangga. Pada jam 13.00 wita Serati Banten Adat telah menyiapkan sarana upakara yang akan dipergunakan pada saat pecaruan nanti antara lain : Caru Panca Sata, Sanggah Surya berada di Timur Caru Panca Sata, Caru Godel yang berada di Barat Daya, Caru Bebek Bulu Sikep diletakan di Timur Laut . Proses upacara ini di pimpin oleh Pemangku Khayangan Tiga. Pelaksanaan Upacara Macaru Sanak Magodel diawali dengan kapertama siratan upakara antuk tirta panglukatan banten.

Mantra "Om Sanghyang tiga murthiyang sanghyang ekaadnyanacuntaka, Sanghyang suci nirmala adnyana mekadi sanghyang sakeluirin banten kareban buat karepuhan ginambel dening wong camah, kaletikan dening odak, karereban dening romon,kaiberan dening sata,kalangkahin dening sona, kaporos dening wed, kaprastitan dening sanghyang tigamurthiniang sanghyang suci nirmala adnyana. Om triya namah swaha”.

Ngastawang bhatara siwa raditya "Om na ma si wa ya ditya dipataye namah swaha".

Mantra "pakulun paduka bhatara sanghyang siwa raditya paduka bhatara sanghyang jagat pati. Pangulaning manusa bhatara angaturing bhakti pangebaktian ipun anyanengane paduka bhatara ring sanggar pamujan dening sopaka raning daksina, manusan bhatara punika ulu anaksikena puja kerti ipun anedesih kerta nugraha ring pada nira bhatara pakulun ameneraken asing luput, amarisuda akena sing kemalan eamah muang campur letuhing sepakaran om yang namu namah swaha".

Matur Piuning di catus pata 
Mantra "Pakulun paduka bhatara sanghyang catus pata manusan nira angaturaken saji taur kasange enak paduka bhatara micayang kerahajengan majeng ring jagat paduka bhatara. Om yang namu namah swaha”.

Pakeling ring ibu pertiwi

Mantra "Ong akasa nirmala sunyam rudra dewa vyomantaram siwa nirbanam wiryanam rekha ong kara wijayam. Ong tejo murthi nama rupem surya candra masriram sarwa teja diptadayanam arcanam sarwa dewanam. Ong akasa bayu murthinam sarwa marana wicitram merthyu kalantaka rodram jagatam pratista lingam. Ong ung Wisnu trinayam caturdewa maha sidhhyam wigna klesa winasanam roga desa wimurcitam. Ong pertiwi sarirandewi catur dewa maha dewi catur asrama bhatari siwa bhumi maha siddyam Ong Ong hrang hring shah wosat sri panca maha bhuta byonamah swaha.

Biukaonan "Om sang kala-kali puniki pabiekaonan katur ring sang kalakali daweg kaluwarane seluwiring kala kabeh kaluwarane dening bhatara muah bhatari, kaluwarane desang kala-kali pukulun, ang ah ya namah swaha".

Pariascita "Om pariyascita karayogi catur warna wicit sayet, catur warnance mesandiem. Om gong reng state tamem”.

Ngemargiang banten Kelemijian

Mantra "Om journa surya, om purna candra, om om suda kles, suda petak sarira utuh, suda dewa sarira bersih ya namah".

Ngemargian Caru Sanak Magodel

Mantra "Om sang kala kabeh, kita wetan, kita kidul, kita kulon, kita sor, kita ring tengah, sira putih, sira bang, sireng kuning, sira ireng, sira manca warna putih rupantaiswara dewankita. Bang rupanta brahma dewankita, kuning rupanta mahadewa dewankita, ireng rupanta wisni dewankita, manca warna rupanta siwa dewankita, iki tandah saji nira caru sarupaning caru iki, enak sira amangang anginum, wus sira amangang anginum, ajata sira salah ulah slah lungguh, mantuk ta sira ring kayangan nira soang-soang. Om sa ba ta a i nama siwaya ang ung mang wastu swaha”.

Tetebus

Mantra "Om rangga wetan angapusakan balung pila-pilu angapusakan otot pilude kadu langgenging. Sanghyang surya mangkana 
langgenging angapusakan linebus tebas, om sampurna ya namah swaha".

Ngayabang ke surya

Mantra "Om Aditya sya paranjotir rakta teja namas tute sweta pangkaja madiaste bhaskara ya nama namu namah, om rang ring siah parama siwa ya namah swaha”.

Ngayaban caru

Mantra " pukulun kaki bhatara kala, paduka bhatari durga, sira bhatara gana, sanghyang panca muka,aya sira anyengkala anyengkali, pakarangane anu, apan sampun ngaturaken caru pabiekalan, amuktia sira, ring sang adruwe caru, teka weras $3 x$. om sang durga bucari ya namah, om sang bhuta bucri ya namah, om khala bucari ya namah, om pisaca bucari ya namah".

Gelarsanga

Mantra "Om buktiantu durga katara buktiantu kala mewasca, buktiantu sarwa betanem, buktiantu pisase sanggieng. Om ang angkala loke boktu ya sai genah".

Setelah proses ini selesai semua yang menyaksikan upacara melaksanakan persembahyangan bersama dan diakhir upacara dilakukan tabuh rah (sabung ayam) di Catus Pata sebagi pertanda upacara Macaru Sanak Magodel di Sasih Kesanga telah selesai.

\section{Tahap Ketiga}

Seusai pelaksanaan upacara Macaru Sanak Magodel di Catus Pata, masing-masing warga mengambil jatah olahan ulam Godel, tirta Khayangan Tiga, dan tirta Kecamatan di bale Banjar setempat, untuk nantinya dipakai upacara Macaru di setiap rumah. Masing-masing krama melaksanakan matur piuning dengan menghaturkan Pejati di Kemulan dan pekarangan rumah, Caru ayam brumbun, Segehan Cacah, Segehan warna lima dados 5 tanding, gelarsanga, selanjutnya di depan rumah menancapkan sanggah cucuk yang berisikan banyotan, tuak, arak, berem, ajengan putih 108, segehan cacahan, berisikan segehan warna 5 dados 5 tanding, olahan ulam Godel.

Foto 4.3

Upacara Macaru di masing-masing rumah warga 


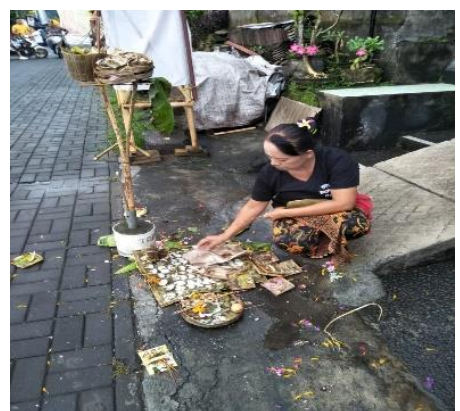

(Dok. Ida Bagus Gede Wijaya : Th 2019)

\subsection{Fungsi Upacara Macaru Sanak Magodel di Sasih Kesanga Desa Adat Abiantuwung}

Setiap upacara yang dilaksanakan umat Hindu pada intinya terkandung fungsi-fungsi tertentu. Teori fungsionalisme struktural menyebutkan fungsi tersebut dapat berupa fungsi yang tampak (manifest) dan fungsi yang tidak tampak (laten). Selain itu terkait dengan ajaran Hindu. Titib (2003:72) menguraikan : fungsi simbol-simbol agama adalah (1) Memantapkan dan meningkatkan sradha (keimanan atau keyakinan) umat dalam rangka menumbuhkan bhakti (ketaqwaan), yang akan membentuk kepribadian umat manusia dengan moralitas yang tinggi yang pada akhirnya akan meningkatkan akhlak luhur masyarakat, (2) Menumbuh-kembangkan dan tetap terpeliharanya nilai-nilai seni budaya melalui seni arca, seni lukis, dan seni kriya lainnya, (3) Memupuk rasa kebersamaan di kalangan umat Hindu dalam mewujudkan sarana pemujaan, utamanya dalam kaitan dengan sakralisasi dan memfungsikan simbol-simbol yang dibuat.

Upacara Macaru Sanak Magodel di Sasih Kesanga Desa Adat Abiantuwung dalam penelitian ini dikaji dari fungsi manifest dan fungsi laten simbol-simbol dalam agama Hindu sangat kompleks dan tergantung dari sisi dan cara mengkajinya. Mengingat keterbatasan penelitian ini, berikut dikaji beberapa fungsi dalam upacara Macaru Sanak Magodel yang paling dirasakan oleh warga masyarakat antara lain.

\subsubsection{Fungsi Keagamaan}

Fungsi keagamaan dalam Upacara Macaru Sanak Magodel di Sasih Kesanga merupakan ungkapan atau perwujudan permohonan kepada Tuhan Yang Maha Esa. Sang Hyang Widhi adalah sumber segalanya dan sumber kebahagiaan hidup serta asal mulai dari segalanya. Melalui upacara ini masyarakat secara tidak langsung dapat melaksanakan pertemuan atau berintergrasi dengan sesama maupun lingkungan, guna mengucapkan syukur, terima kasih dan memohon keselamatan kepada Tuhan Yang Maha Esa.

Dapat ditegaskan bahwa fungsi keagamaan upacara Macaru Sanak Magodel adalah merupakan menumbuhkan dan mengembangkan kesadaran masyarakat akan pentingnya pelaksanaan upacara dalam memahami dan melaksanakan ajaran agama. Menumbuhkan kesadaran warga masyarakat 
akan pelaksanaan upacara agama seta dapat membangun nilai-nilai spiritual positif, agar terciptanya keseimbangan yang harmonis.

\subsubsection{Fungsi Religius}

Koentjaraningrat (1987: 58) azas asal mula religi digolongkan kedalam tiga golongan ketiga golongan teori itu adalah : (1) teori yang dalam pendekatannya berorientasi kepada keyakinan religi; (2) teori-teori yang dalam pendekatannya berorientasi pada sikap manusia terhadap alam gaib atau hal yang gaib; (3) teori yang dalam pendekatannya berorientasi kepada upacara religi.

Karena pada saat Sasih Kesanga merupakan sasih yang paling kotor, sehinga dilaksanakan upacara macaru di Provinsi, masing-masing Kabupaten, masing-masing Desa Adat dan pekarangan rumah. Caru Sanak Magodel mempunyai fungsi penetralisir Bhuta Kala, dan menyeimbangkan Bhuana Agung, Bhuana Alit serta memohon keselamatan lahir dan bhatin. (Wawancara I Nyoman Badra, tgl 8 Maret 2019).

Secara nyata Upacara Macaru Sanak Magodel di Sasih Kesanga dilakukan kepada lima unsur alam tersebut (Panca Maha Bhuta), dengan menjadikan diri harmonis dengan alam, diwujudkan moral dengan pelestarian, menjaga ekologi sehingga tercipta keharmonisan di kehidupan dan alam. Berikut adalah penjelasan dari unsur-unsur Panca Maha Bhuta beserta contohnya.

a.Prthiwi : merupakan unsur zat padat pembentuk alam, unsur padat ini berupa tanah, sedangkan pada badan manusia pertiwi adalah badan kasar atau tubuh manusia itu sendiri.

b. Apah : merupakan unsur zat cair pembentuk alam, maka jika kita lihat pada alam semesta unsur cair ini berupa air laut, air danau, air tawar dan segala bentuk cair lainnya, sedangkan pada tubuh manusia unsur cair berupa darah, keringat dan segala yang cair pada tubuh manusia.

c. Bayu : merupakan unsur gas pembentuk alam, unsur gas ini berupa udara yang berhembus di alam semesta atau gas yang dihasilkan oleh pepohonan, sedangkan pada manusia unsur gas ini berupa proses pernafasan yang menghirup $\mathrm{O} 2$.

d.Teja : merupakan unsur panas penyusun alam, jika pada alam semesta kita bias melihat api, panas bumi, sedangkan tubuh manusia panas ini sebagai indikator suhu tubuh. 
e. Akasa : merupakan unsur ruang penyusun alam, jika pada alam semesta dengan ruang angkasa, galaksi, rotasi bumi dan planet, sedangkan pada tubuh manusia adanya lubang telinga, lubang hidung dan tenggorokan yang berfungsi untuk jalan atau sirkulasi dari unsur lainnya.

\subsubsection{Fungsi Penyucian}

Yadnya dalam bentuk Upacara Macaru Sanak Magodel di Sasih Kesanga, tidak hanya merupakan tindakan penghormatan sebagai wujud bhakti kepada Ida Hyang Widhi Wasa yang telah berkenan melimpahkan karunia-Nya kepada umat manusia, namun terkandung pula fungsi penyucian.

Fungsi Penyucian ini dapat dilihat dari sarana yang dipergunakan diantaranya air suci (tirtha) lengkap dengan suplemennya yang berupa puja (mantra). (Wiana 1995 : 12) menyatakan ada lima unsur panyucian yang dikandung dalam upacara agama Hindu. Kelima unsur yang terpadu itu yakni mantra, yantra, tantra, yadnya dan yoga. Mantra merupakan doa yang diucapkan oleh Pinandita atau Pendeta sesuai dengan tingkatannya. Upacara Macaru Sanak Magodel di Sasih Kesanga, sarat sekali dengan fungsi penyucian. Penyucian dalam upacara ini diantaranya menyucikan catus pata (empat mata arah angin), dan penyucian kepada Panca Maha Bhuta.

\section{PENUTUP}

Bentuk pelaksanaan upacara Macaru Sanak Magodel di Sasih Kesanga Desa Adat Abiantuwung merupakan suatu tradisi yang harus dilaksanakan setiap tahun, biasanya jatuh pada bulan Maret, nemonin Tilem Kesanga tepatnya Sasih Kesanga. Upacara tersebut diyakini oleh warga masyarakat dapat menyeimbangkan Bhuana Alit dan Bhuana Agung, menghilangkan leteh pada sifat-sifat negatif. Proses awal upacara Macaru Sanak Magodel dilakukan dengan mempersiapkan sarana upakara yang dilakukan oleh Serati Banten Desa Adat Abiantuwung beberapa hari sebelum pelaksanaan, kemudian pada saat Tilem Kesanga sebelum pemotongan Godel dilakukan proses Mepepada di Bale Agung Pura Puseh, barulah warga laki-laki mulai dari subuh dengan menguliti Godel karena dipakai untuk bayang-bayang. Daging Godel diolah menjadi berupa Bayuhan dan Karangan. Setelah pelaksanaan pengolahan daging Godel, 
warga Desa Adat Abiantuwung melaksanakan upacara Macaru Sanak Magodel di Catus Pata. Setelah upacara ini selesai masing-masing warga setiap pekarangan nunas olahan Godel dan Tirtha Khayangan di masingmasing Bale Banjar. Setelah waktu menunjukan Sandikala, warga masyarakat Desa Abiantuwung melakukan pecaruan di pemesuan (pintu masuk rumah) dengan olahan Godel. Fungsi upacara Macaru Sanak Magodel di Sasih Kesanga Desa Adat Abiantuwung yaitu : fungsi keagamaan, fungsi religius, fungsi penyucian merupakan fungsi utama dalam upacara Macaru Sanak Magodel di Desa Adat Abiantuwung, dimana menumbuhkan kesadaran warga masyarakat akan pelaksanaan upacara agama, menjadikan diri harmonis dengan alam, menjaga ekologi serta menciptakan keharmonisan dalam kehidupan sosial dan dapat menyucikan Panca Maha Bhuta, Catus Pata.

\section{DAFTAR PUSTAKA}

Anwar, Dessy. 2006. Kamus Lengkap Bahasa Indonesia. Surabaya : Karya Abditama.

Arikunto Suharsimi. 1986. Presedur Penelitian Suatu Pendekatan Praktik. Jakarta : Rineka Cipta.

Arikunto, S. 2002. Metodelogi Penelitian. Yogyakarta : Bina Aksara.

Bungin, Burhan. 2006. Metodologi Penelitian Kualitatif. Jakarta.

Endraswara, Suwardi. 2003. Metodelogi Penelitian Kebudayaan. Gajah Mada University Pers.

Darmayudha, I Made Suasthawa. 2005. Desa Adat Kesatuan Masyarakat Hukum Adat di Propinsi Bali. Bali : Upada Sastra.

Gulo. 2002. Metodelogi Penelitian. Jakarta : Rineka Cipta.

Hasan, Iqbal. 2002. Metodelogi Penelitian dan Aplikasinya. Jakarta : GI.

Koentjaraningrat. 1987. Sejarah Teologi Antropologi II. Jakarta : Universitas Indonesia Pers.

Koentjaraningrat. 1997. Antropologi Budaya. Jakarta : Dian Rakyat.

Mas Putra. 2000. Upacara Yadnya. Dinas Agama dan Budha. Denpasar.

Nada Atmaja, dkk. 2010. Etika Hindu. Surabaya: Paramita.

Narawi, Hadari. 2005. Metode Penelitian Bidang Sosial. Yogyakarta : Gajah Mada.

Ridwan. 2006. Belajar Mudah Penelitian Untuk Guru, Karyawan, dan Peneliti Pemula. Bandung : Alfabeta. 
Sonhadji. 1994. Medotelogi Research. Jakarta : Penerbit Balai Pustaka.

Sudarsana, Drs.I.B.Putu. 2001. Ajaran Agama Hindu, Makna Upacara Bhuta Yadnya. Denpasar : Yayasan Dharma Acarya.

Sudarsana, Drs.I.B.Putu. 2014. Ajaran Agama Hindu, Filasafat Yadnya. Denpasar : Yayasan Dharma Acarya.

Sudarsana, I.B. Putu dan Ripig. Ni Wayan, dkk. Himpunan Tetandingan Upakara Yadnya. Yayasan Dharma Acarya, Edisi III, 1998.

Supadmiati, Ni Wayan. 2009. Upacara Pecaruan Tilem Kewulu Di Desa Adat Penatahan Kecamatan Penebel, Kabupaten Tabanan. Denpasar : UNHI.

Suriani, Ni Made. 2017. Upacara Mecaru Sasih Kenem di Desa Pekraman Laplap Penatih Dangin Puri, Kecamatan Denpasar Timur, Kabupaten Denpasar. Denpasar : UNHI

Suryani, Dra.I.Gusti Ayu Putu. 2011. Ritual Bhuta Yadnya. Denpasar : Udayana University Press.

Swastika, Mangku. I Ketut Pasek. 2013. Bhuta Yadnya. Denpasar : Pustaka Bali Post.

Tim Penulis, 2000. Panca Yadnya, Denpasar. Proyek Peningkatan Sarana dan Prasarana Kehidupan Beragama Tersebar di 9 (Sembilan) Daerah Tingkat II.

Titib, I Made. 2001. Teologi \& Simbol-simbol. Surabaya. Paramitha

Triguna, Ida Bagus Gde Yuda. 2000. Teori Tentang Simbol. Denpasar. Widya Dharma UNHI

Umayanti, Kadek Ewik. 2017. Upacara Mecaru Godel Bang di Pura Prajapati Desa Adat Bunutin, Kabupaten Bangli. Denpasar : UNHI

Weda, I Ketut. 2004. Makna Upacara Yadnya dalam Agama Hindu. Paramita Surabaya.

Wikarman, Drs I Nyoman Singgin. 1998. Caru. Surabaya : Paramita Surabaya.

Wikarman, Drs I Nyoman Wikarman Singgin. 2006. Caru Palemahan dan Sasih. Surabaya : Paramita Surabaya.

Wijayanda, Ida Pandita Mpu Jaya. 2004. Makna Filosofi Upacara dan Upakara. Surabaya : Paramita. 